\title{
PENGEMBANGAN MODEL PEMBELAJARAN AKTIVITAS JASMANI MELALUI PERMAINAN TRADISIONAL BAGI SISWA SEKOLAH DASAR
}

\author{
Dyah Frika Lestari
}

\author{
Fakultas Pendidikan Guru Sekolah Dasar \\ Universitas PGRI Semarang \\ Email:dyahfrika24@gmail.com
}

\begin{abstract}
Abstrak
Pada penelitian ini bertujuan untuk (1). Menghasilkan model pengembangan pembelajaran berbasis aktivitas jasmani dalam karakter disiplin yang disajikan sesuai dengan tema pembelajaran kelas III SD, (2) Menguji keterlaksanaan model pengembangan pembelajaran berbasis aktivitas jasmani dalam karakter disiplin yang disajikan sesuai dengan tema pembelajaran kelas III sekolah dasar, (3) Menguji ketertarikan peserta didik terhadap model pengembangan pembelajaran berbasis aktivitas jasmani dalam karakter disiplin yang disajikan sesuai dengan tema pembelajaran kelas III sekolah dasar. Teknik pengumpulan data menggunakan pedoman observasi Pengumpulan data yaitu dengan observasi, terhadap pembelajaran Pendidikan Jasmani di SD N Sendangmulyo 01 Semarang Kelas III, Wawancara kepada guru Pendidikan PJOK,studi dokumentasi, angket atau kuisioner, rekaman vidio kegiatan pembelajaran ketika dilapangan kemudian di konversikan ke data pengembangan kualitatif. Subjek penelitian adalah siswa kelas III di SD N 01 Sendangmulyo Semarang. Penelitian ini menunjukkan bahwa hasil validasi yang dilakukan diperoleh persentase rata-rata penilaian sebesar $85,25 \%$ diterima dengan baik. Berdasarkan hasil peneltian dan pembahasan dapat disimpulkan bahwa model pembelajaran aktivitas jasmani melalui permainan tradisional bagi siswa sekolah dasar dapat meningkatkan rasa senang dan percaya diri pada siswa.
\end{abstract}

Kata Kunci: pengembangan, model pembelajaran penjas

\begin{abstract}
In this study aims to (1). Generating a model of development of learning based on physical activity in the character of discipline presented in accordance with the theme of learning in class III SD learners towards the development model of learning based on physical activity in the character of the discipline presented in accordance with the theme of learning in grade III elementary school. Data collection techniques using observation guidelines Data collection is observation, on learning Physical education at SD N Sendangmulyo 01 Semarang Class III, Interview with PJOK Education teachers, study documentation, questionnaire or questionnaire, video recording of learning activities when in the field and then converted to development data Research and Development $(R n D)$. The subjects were grade III students at SD N 01 Sendangmulyo Semarang. This study shows that the validation results obtained an average percentage of assessment of $85.25 \%$ is well received. Based on the results of the study and discussion it can be concluded that the physical activity learning model through traditional games for elementary school students can increase the sense of confidence in students.
\end{abstract}

Keywords: development, Physical education learning model 


\section{PENDAHULUAN}

Menurut UU No.20 Tahun 2003 Pendidikan adalah usaha sadar dan terencana untuk mewujudkan suasana belajar dan proses pembelajaran agar peserta didik secara aktif mengembangkan potensi dirinya untuk memiliki kekuatan spiritual, keagamaan, pengendalian diri, kepribadian, kecerdasan, akhlak mulia, serta keterampilan yang diperlukan dirinya, masyarakat, bangsa, dan negara. Tujuan Pendidikan Jasmani, Olahraga dan Kesehatan menurut Permendiknas No. 22 Tahun 2006 menyatakan bahwa untuk mengembangkan aspek kebugaran jasmani, keterampilan gerak, keterampilan berfikir kritis, keterampilan sosial, penalaran, stabilitas emosional, tindakaan moral dan aspek pola hidup sehat. Pendidikan jasmani bukan hanya merupakan bagian penting bagi kehidupan manusia saja, Tetapi berolahraga dapat meningkatkan kesegaran jasmani dan kondisi fisik seseorang (Muhardi \& Wijayanti, 2017), sehingga untuk melaksanakan aktivitas sehari-hari tanpa. mengalami kelelahan yang berarti. Melalui kegiatan olahraga dapat membentuk manusia yang sehat jasmani dan memiliki watak disiplin serta sportif yang tinggi dan pada akhirnya akan membentuk manusia yang berkualitas. Dimana karakter disiplin juga diperlukan dalam penjas. Kedisiplinan merupakan suatu kondisi yang tercipta dan terbentuk melalui proses dan serangkaian perilaku yang menunjukkan nilai-nilai ketaantan, kepatuhandan, kesetiaan, keteraturan dan ketertiban. Pendidikan jasmani juga merupakan bagian penting dari proses pendidikan. Artinya, melalui pendidikan jasmani yang diarahkan dengan baik, anak akan mengembangkan keterampilan yang berguna bagi pengisian waktu senggang, terlibat dalam aktivitas yang kondusif untuk mengembangkan hidup sehat, berkembang secara sosial, dan menyumbang pada kesehatan fisik dan mentalnya.

Dini Rosdiana, 2012 ) olahraga adalah setiap aktivitas yang mengandung sifat atau ciri permainan dan melibatkan unsur perjuangan mengendalikan diri sendiri atau orang lain atau konfrontasi dengan factor alam. Pendidikan jasmani banyak permasalahan yang muncul pada saat berlangsungnya proses belajar mengajar yaitu seperti anak didik timbul sifat bermalas-malasan untuk melakukan aktivitas jasmani. Saat kegiatan belajar mengajar anak didik pura-pura sakit,ijin, bahkan adapula ketika sedang melakukan olahraga siswa yang malas hanya duduk-duduk saja, bakhan tidak mau bergerak setelah teori yang diajarkan sudah selesai dan tidak mengikuti pelajaran dengan berbagai macam alasan. Sehingga ketika anak bermain atau diberi permainan dalam rangka pelajaran pendidikan jasmani, maka anak akan melakukan permainan itu dengan rasa senang. Karena rasa senang inilah maka anak akan mengungkap keadaan pribadinya yang asli pada saat mereka bermain, baik itu berupa watak asli, maupun kebiasaan yang telah membentuk kepribadiannya. Dengan memberikan materi mengenai permainan tradisional untuk meningkatkan efektivitas pembelajaran pendidikan jasmani dengan tujuan agar proses belajar pendidikan jasmani menjadi suatu hal menyenangkan dan dinanti-nantikan siswa serta dapat mencapai tujuan dari pendidikan jasmani itu sendiri yaitu meningkatkan kualitas dan sumber daya manusia. Sesuai dengan pembelajaran di PJOK saat ini adalah hakekatnya pendidikan jasmani merupakan Pendidikan yang memanfaatkan aktivitas fisik untuk membugarkan dan menghasilkan perubahan holistik dalam kualitas individu, baik dalam hal fisik, mental dan emosional (Hartono dkk, 2013: 2). 
Sekolah Dasar merupakan jenjang pendidikan yang membekali atau memberikan dasar-dasar dan mempersiapkan peserta didik untuk mengikuti pendidikan pada jenjang berikutnya.sehingga model pembelajaran pada penjas berbasis penerapan karakter disiplin pada siswa sangtlah penting. Pada saat melaksanakan pembelajaran pendidikan jasmani seorang guru harus aktif menciptakan suasana pembelajaran yang sebaik mungkin agar motivasi belajar siswa dapat meningkat. Tujuan pembelajaran dapat tercapai dengan baik bila seorang guru memiliki kemampuan untuk membangkitkan motivasi siswa dalam belajar. Dalam rangka mencapai tujuan tersebut, pembelajaran yang dilakukan antara guru dan siswa hendaknya mengacu pada aktivitas dan partisipasi siswa. Guru tidak hanya melakukan kegiatan penyampaian pengetahuan,keterampilan, dan sikap kepada siswa akan tetapi guru diharapkan mampu membawa siswa untuk aktif dalam berbagai bentuk pembelajaran. Gerak dasar pada anak ini adalah gerak dasar motoric yaitu gerak dasar lokomotor, non lokomotor (stabilitas) dan manipulatif. Anak usia sekolah dasar merupakan individu yang selalu aktif melakukan pemberontakan baik dengan dirinya sendiri, maupun terhadap lingkungan sekitarnya. Jadi dengan kata lain bermain itu aktivitas yang penuh dengan nuansa keriangan yang memilikitujuan yang melekat didalamnya untuk kegembiraan dan kesenangan (Hartati, dkk, 2012: 3).

Dari hasil observasi peneliti medapatkan hasil bahwa dari 35 siswa pada saat pembelajaran penjas berlangsung 85,25 \% merasa senang dengan model pembelajaran yang telah diberikan. Dimana sebelumnya pendidik penjas hanya menggunakan media alat yang sesuai dengan materi. Dalam penjelasan pun kurang jelas peserta didik hanya $50 \%$ yang memperhatikan. Dengan hasil akhir Ketika peserta didik melakukan permainan kurang paham, sehingga pendidik mengulang Kembali materi yang sudah dijelaskan. Ketika peneliti memberikan media pembelajaran yang sesuai tema dan materi diberikan model

pembelajranpermaianantradisionalpesert adidik $85,25 \%$ merespondenganbaik.

Berdasarkan latar belakang tersebut maka peneliti bermaksud mengembangkan model pembelajaran berbasis aktivitas jasmani dengan hasil penelitian tentang penerapan permainan tradisional pada pembelajaran penjas . Model pembelajaran PJOK bagi para guru pengajar dan diterapkan pada proses pembelajaran PJOK untuk memperkenalkan pada siswa nilai-nilai budaya yang terkandung dalam permainan tradisional tersebut. Dimana terdapat pengaruh pemberian permainan tradisional terhadap efektivitas pembelajaran pendidikan jasmani, kesehatan dan olahraga pada siswa kelas SD ( Sekolah Dasar).

\section{METODE}

Metode yang digunakan dalam penelitian ini adalah R\&D (Research and Development) Borg dan Gall dalam Wahyudi

Memberikan pengertian penelitian pengembangan adalah proses penelitian yang digunakan untuk mengembangkan dan mengesahkan produk bidang pendidikan yang lebih baik dari sebelumnya yakni pengembangan produk berupa model pembelajaran penjas untuk siswa SD kelas III yang dilakukan dengan tahapan sebagai berikut: (1) analisis kebutuhan produk, (2) mengembangkan produk awal, (3) melakukan validasi ahli, (4) melakukan uji coba skala kecil dan skala besar, (5) revisi produk dan (6) produk akhir. Teknik pengumpulan data menggunakan pedoman observasi dan kuisioner dengan teknik analisis data menggunakan statistik deskriptif kemudian di konversikan ke 
datakualitatif.

Subjek yang digunakan dalam penelitian ini adalah siswa kelas III Sekolah Dasar 01 Sendangmulyo Semarang dengan jumlah 35 siswa. Yang dillaksanakan pada tahun 2019 .

Jenis data awal yang diperoleh pada penelitian ini yaitu data kualitatif dan data kuantitatif dengan pengumpulan data melalui observasi, wawancara, studi dokumentasi, angket atau kuisioner, rekaman video selama pelaksanaan pembelajaran penjas berlangsung. Teknik tersebut yang nantinya digunakan dalam penelitian ini.

Prosedur penelitian ini, mengacu terhadap produk bahan ajar yang dikembangkan Instrumen yang dikembangkan dan digunakan dalam penilaian ini meliputi Instrumen penelitian dalam tahap uji coba produk menggunakan angket atau kuisioner. Penelitian ini menggunakan angket yaitu angket validasi ahli media, angket validasi ahli materi,uji skala kecil dan uji skala besar.Teknik analisis data kuantitatif hasil penilaian ahli dan praktisi terhadap bahan ajar yang dikembangkan menggunakan deskriptif kuantitatif dengan menggunakan presentase.

\section{HASIL DANPEMBAHASAN}

Hasil dari penelitian dan pengembangan model pembelajaran penjas melalui permainan tradisional dapat dijabarkan sebagai berikut :

Produk awal model aktivitas belajar gerak berbasis permainan sebagai materi ajar pendidikan jasmani di sekolah dasar kelas III sebelum diujicobakan dalam uji kelompok kecil perlu dilakukan validasi oleh para ahli yang sesuai dengan bidang penelitian ini. Adapun hasil dari validasi tersebut adalah:

Dari hasil validasi oleh ahli media berdasarkan penilaian aspek rekayasa perangkat media pembelajaran, desain media pembelajaran dan manfaat aplikasi diperoleh persentase $79 \%$ dengan kategori sangat layak. Adapun hasil dari vaidasi ahli media dapat dilihat pada Tabel 1.

Tabel 1. Rekapulasi Hasil Penelitian

No. AspekPenilian Presentase \%

Validasi Ahli Media 1. RekayasaPerangkat Media
pembelajaran

$89,28 \%$

2. Desain media pembelajaran

$89,28 \%$

3. Pemanfaatan media pembelajaran $66,67 \%$

Validasi Ahli Materi

4. SubtansiMateri

$85,00 \%$

5. Desainpembelajaran

$95,00 \%$

KeterimaanPesertaDidik

6. Uji skalakecil $79,20 \%$

$90,00 \%$ 
7. Uji skalabesar

Jumlah

Rata-rata
586,4

83,78
Berdasarkan hasil penelitian dan pembahasan tentang pengembangan model pembelajaran penjasorkes untuk sekolah dasar kelas III SD N 01 Sendangmulyo, maka dapat disimpulkan sebagai berikut :Dengan rekayasa perangkat media pembelajaran presentase $81,25 \%$. Desain media pembelajaran $89,28 \%$. Pemanfaatan media 66,67\%. Dari validasi ahli media dapat dilihat bahwa pemanfaatan media pembelajaran sebtansi pada materi diperoleh presentase 90\%. Sedangkan pada analisis validasi ahli materi memiliki aspek penilian subtansi materi terdapat presentase $85 \%$. Desain pembelajaran 95\%. Dari hasil uji praktisi Validasi ahli materi dapat disimpulkan bahwa materi yang digunakan dalam pembelajaran diperoleh presentase 93\% dengan kategor ilayak. Sedangkan pada analisis validasi uji coba skala besar $79,20 \%$, uji skala besar $90,00 \%$. Dengan rata-rata 83,78.

Melalui model yang telah diberikan dalam pembelajaran penjas melalui model permainan tradisional peserta didik merasa sangat senang dan tertarik dalam melakukan kegiatan pembelajaran penjas. Dengan demikian produk pengembangan dari pembelajaran penjasorkes yang dihasilkan membuat pembelajaran menjadi lebih menarik, menyenangkan, kontekstual dan menunjang pembelajaran mata pelajaran lain sesuai dengan tema yang ada. Dengan demikian produk pengembangan dari pembelajaran penjasorkes yang dihasilkan membuat pembelajaran menjadi lebih menarik, menyenangkan, kontekstual dan menunjang pembelajaran mata pelajaran lain sesuai dengan tema yang ada. Sehingga model pembelajaran yang diterapkan dalam pembelajaran penjas sangat layak digunakan untuk membangun semangat peserta didik dan membagun keterampilan bagi peserta didik khususnya pada Pendidikan jasmani sekolah dasar.

\section{SIMPULAN}

Berdasarkan hasil penelitian dan pembahasan tentang pengembangan model aktivitas jasmani melalui permainan tradisional bagi siswa kelas III sekolah dasar dapat mempengaruhi hasil belajar siswa dengan kesimpulan : (1) peserta didik merasa senang dan meningkatan rasa ingin tau yang lebih besar. (2) Model pembelajaran tematik materi penjasorkes dapat meningkatkan kemampuan peserta didik pada aspek psikomotor, kognitif dan afektif. (3) pada penerimaan pemahaman siswa dalam skala kecil terdapat $79,20 \%$,skala besar $90,00 \%$. Dengan rata-rata 83,78 .

\section{DAFTAR PUSTAKA}

Departemen Pendidikan Nasional. 2003. Undang-Undang Republik Indonesia Nomor 20 Tahun 2003 tentang Sistem Pendidikan Nasional
Departemen Pendidikan Nasional. 2006.Peraturan Menteri Pendidikan Nasional (Permendiknas) Nomor 22 tahun 2006

Muhardi, M., \& Wijayanti, N. P. N. (2017). Tingkat kesegaran jasmani siswa 
SMPN1Bangko Kabupaten Rokan Hilir. Jurnal Online Mahasiswa (JOM) Bidang Keguruan dan IImu Pendidikan, 3(2), 1-10.

Rosdiani, Dini. (2012). Dinamika Olahraga dan Pengembangan Nilai. Bandung.
Pendidikan Jasmani (Sebuah Pengantar). Surabaya: Unesa University Press

Hartati, Sasminta Christina Yuli, dkk. 2012. Permainan Kecil. Malang: Wineka Media.

Hartono, Soetanto, dkk. 2013. 